\title{
Global production networks and the analysis of economic development
}

\section{Jeffrey Henderson, Peter Dicken, Martin Hess, Neil Coe and Henry Wai-Chung Yeung}

University of Manchester and National University of Singapore

\begin{abstract}
This article outlines a framework for the analysis of economic integration and its relation to the asymmetries of economic and social development. Consciously breaking with state-centric forms of social science, it argues for a research agenda that is more adequate to the exigencies and consequences of globalization than has traditionally been the case in 'development studies'. Drawing on earlier attempts to analyse the cross-border activities of firms, their spatial configurations and developmental consequences, the article moves beyond these by proposing the framework of the 'global production network' (GPN). It explores the conceptual elements involved in this framework in some detail and then turns to sketch a stylized example of a GPN. The article concludes with a brief indication of the benefits that could be delivered by research informed by GPN analysis.
\end{abstract}

\section{KEYWORDS}

Globalization; economic development; business networks; institutions; embeddedness.

The analysis of economic development has been bedevilled by a series of analytic disjunctions that have resulted in work either at macro or meso levels of abstraction or, where empirical investigations have probed micro level processes, the larger analytic picture has often been absent, merely implicit, or at best weakly developed. While there are notable exceptions to this general rule (for instance, Armstrong and McGee, 1985) behind it lies half a century and more of scholarship in development economics (irrespective of its paradigmatic stripe) and in the political economy and sociology of development. ${ }^{1}$ What is more, from the beginnings of 'dependency' approaches to development in the 1940s through to debates over the respective roles of states and markets in the East 
Asian 'miracle' and its recent demise, the central agent in development has often been perceived as the state, whether the assessment of its role has been positive or negative. ${ }^{2}$ Although the developmental significance of labour, gender and other social movements as well as international agencies such as the IMF and World Bank, have figured in radical analyses, the analytic space given to development actors other than these, has been limited.

Nowhere is this relative absence more obvious than with regard to the firm. Although there is a long history of work on foreign investment and development (summarized, for instance, in Jenkins, 1987 and Dicken, 1998), this has tended to deal largely with the role of transnational corporations (TNCs) and has relied primarily on secondary data for its empirical bases. Little of it has probed the organizational dynamics of TNC subsidiaries as they emerge, evolve and impact on particular economies and even less of it has dealt with domestic firms, be they associated or not with foreign companies. ${ }^{3}$

There is, of course, a considerable amount of research on firms that has been conducted by sociologists of work and organization and by specialists in management studies. However, this has been largely confined to companies in developed economies and the former state-socialist societies of Central and Eastern Europe, and where it has been conducted by management specialists, it has remained outside the social science mainstream and thus has largely failed to influence (or be influenced by) more general discourses. Where work of this nature has been conducted in the developing world, it has been done largely by feminist researchers and has tended to engage more with gender-related issues than with the broader questions of industrial organization and economic development (see for instance, Heyzer, 1986; Mitter and Rowbotham, 1995).

A further - and given contemporary circumstances, perhaps fatal analytic disjuncture is that research on economic development (as with the vast majority of social science) has been state-centric in its assumptions and analyses. ${ }^{4}$ While world-systems theory has provided an analytic framework that promises to move beyond these limitations, it is a framework that has yet to act as a significant guide to empirical work on contemporary problems of development. In this context, the national state continues to be the conventional unit of analysis for the majority of studies of the world economy. However, exclusive attention to this level of aggregation is becoming les useful in light of the changes occurring in the organization of economic activities which increasingly tend to slice through, while still being unevenly contained within, state boundaries.

Indeed, Castells has argued that the world is being transformed from a 'space of places' into a 'space of flows' (Castells, 2000a, 2000b). More accurately, perhaps, the world is now constituted by both a space of places 
and a space of flows and thus a key issue has become the nature of the dialectical relation between these spaces and the consequences of that relation.

In order to understand the dynamics of development in a given place, then, we must comprehend how places are being transformed by flows of capital, labour, knowledge, power etc. and how, at the same time, places (or more specifically their institutional and social fabrics) are transforming those flows as they locate in place-specific domains. Globalization (for that is the shorthand for our concerns) has undercut the validity of traditional, state-centred, forms of social science, and with that the agendas that hitherto have guided the vast majority of research on economic and social development. Investigations adequate to the study of globalization and its consequences demand of social scientists the elaboration of analytic frameworks and research programmes that simultaneously foreground the dynamics of uneven development transnationally, nationally and sub-nationally. Such investigations require us to focus on the flows and the places and their dialectical connections as these arise and are realized in the developed and developing worlds alike. Additionally, if the object of our endeavours is the possibilities for economic development and prosperity, then we should recognize that in order to speak authoritatively on these issues, we need to study what firms do, where they do it, why they do it, why they are allowed to do it, and how they organize the doing of it across different geographic scales.

In this article we outline an analytic framework which, we believe, helps us to understand some of these processes more effectively. The framework we propose is that of the 'global production network' (GPN). While the GPN is not advanced as a totalizing framework capable of grasping the myriad complexities of economic globalization, we believe that it is capable of delivering a better analytic purchase on the changing international distribution of production and consumption - and the viability of different development strategies to which they relate - than has previously been possible.

We begin with some brief critical reflections on the most relevant precursors to our work. We then outline the conceptual elements of the GPN and, in so doing, highlight the reasons for its analytic superiority over competing frameworks. Penultimately we present a stylised example of a GPN and conclude with a brief comment on the benefits that GPN research could deliver.

\section{CRITICAL REFLECTIONS ON RELATED APPROACHES}

Over the past 20 years or so, a plethora of studies has emerged using some variant or another on the concept of chains or networks. ${ }^{5}$ The result is a considerable degree of confusion in the use and meaning of the 
terminologies employed (cf. Sturgeon, 2001). Although the approaches often overlap with one another they derive from different intellectual domains and, therefore, carry with them different kind of intellectual 'baggage'. One difference between these approaches is between those that stem from the business-managerial literature and those that have evolved within an economic-developmental framework. A second difference is between those that employ a 'chain' metaphor and those that adopt a 'network' perspective (although the distinction is not always clear-cut).

\section{Chain concepts}

The value chain or value-adding chain is an old-established concept in industrial economics and in the business studies literature. It has been used most prominently by Michael Porter $(1985,1990)$ and has achieved very wide currency in the management community. Like all uses of the chain metaphor its value lies in its emphasis on the sequential and interconnected structures of economic activities, with each link or element in the chain adding value to the process (value being defined in terms of the pay-off to the business firm). For our purposes, Porter's conceptualization has a limited utility because it is bounded by the firm or interfirm network and pays no attention to issues of corporate power, the institutional contexts of - and influences upon - firm-based activities, or to the territorial arrangements (and their profound economic and social asymmetries) in which the chains are embedded. As a consequence, it has little relevance for the study of economic development.

Of greater importance is the concept of the filière, which is defined as a system of agents producing and distributing goods and services for the satisfaction of a final demand. Developed in the 1970s by French economists in order to achieve a more structured understanding of economic processes within production and distribution systems (Lenz, 1997: 21 ), the concept stems from a predominantly empirical tradition, the main objectives of which are to map commodity flows and to identify the agents and activities within the filière (Raikes et al., 2000: 404-5). By doing so, hierarchical relationships between the agents can be identified, allowing for a detailed analysis of the dynamics of economic integration and disintegration.

It is difficult to identify a distinct theoretical core for the filière approach. Indeed, there is a plurality of theories underlying recent filière analyses, particularly those of regulation and convention theory. ${ }^{6}$ Although the filière approach focuses on agents within the system, as well as on dependency and the distribution of power, it concentrates mainly on two types of agent - large firms and (national) state institutions - and how their scope of activity is limited by technological constraints. Hence the 
spectrum of agents in production networks, their role in shaping these networks and thus influencing development at different scales, is only partially dealt with.

By far the most useful of the chain conceptualizations of economic activities is Gary Gereffi's global commodity chain (GCC). The characteristics of the GCC framework have been extensively outlined both in Gereffi's own writings (see, for example, Gereffi and Korzeniewicz, 1994; Gereffi, 1995, 1999a) and in appraisals by others (see, for example, Dicken et al., 2001; Czaban and Henderson, 1998; Whitley, 1996) so there is no need for recuperation here. It is important, however, to understand the intellectual lineage of Gereffi's GCC concept and the extent to which it may meet our needs.

Gereffi's work is set within the (broadly defined) 'dependency' tradition of analysis. In focusing on the dynamics of the global organization of production, however, it has a particular affinity with the work in the late 1970s and 1980s on the emergence of a 'new international division of labour' and its economic and socio-spatial consequences (cf. Fröbel et al., 1980; Henderson and Castells, 1987; Henderson, 1989). As with the work of Fröbel and his colleagues, Gereffi's contribution was an explicit attempt to operationalise some of the world-systems categories for the empirical study of cross-border, firm-based transactions and their relation to development (Gereffi, 1995). Unlike their work, however, it broke with the static (and now empirically redundant) spatial categories of the core/semiperiphery/periphery typology and, as such, was better able to grasp the reality of the 'new' forms of industrial organisation that had become the objects of scholarly attention during the 1980s and 1990s.

For Gereffi and his collaborators, global commodity chains consist of:

sets of interorganizational networks clustered around one commodity or product, linking households, enterprises, and states to one another within the world-economy. These networks are situationally specific, socially constructed, and locally integrated, underscoring the social embeddedness of economic organization.

(Gereffi et al., 1994: 2)

With the exception of trade unions and other NGOs, this definition incorporates most of the elements relevant to the organization of firm and inter-firm networks and their relation to the possibilities for economic and social development. However, only a few of these elements have been followed through empirically or analytically by Gereffi, his collaborators, or others who have worked in this vein. ${ }^{7}$ In particular, the focus has been overwhelmingly on the governance dimension of GCCs and on a bimodal distinction between producer-driven and buyer-driven GCCs at that. This distinction, however, is a crude one and it leads to problems. 
First, although the rationale for this distinction lies in differential barriers to entry into the various product markets (Dicken et al., 2001), it is clear that the distinction is intended to refer to sectorally and organizationally specific empirical realities. It is not, then, an ideal-typical construction.

Second, much of the work from within the GCC tradition has been concerned with currently existing chains. Hardly any of it seeks to re-construct the history of the nature and implications of the chains. This is an important omission because the social relations embodied in chains at one point in time impose a path-dependency and constrain the future trajectories of chain development. For example, the institutional contexts and social arrangements of the state-socialist period linger on and circumscribe in important ways the potential for economic and political development in the 'transitional' economies of Eastern Europe (cf. Stark, 1992; Hausner et al., 1995; Czaban and Henderson, 1998).

Third, there have been few attempts to understand the significance of firm ownership (domestic or foreign, and in the latter case, by nationality) for economic and social development in particular societies. Even though this 'silence' may be a product of the GCC scheme's primary concern with buyer-driven chains, there is clearly a need to recognize that the 'nationality' of firm ownership may be a key element in economic and social progress. ${ }^{8}$

The fourth problematic issue for the GCC framework is the fact that commodity chains link not only firms in different locations, but also the specific social and institutional contexts at the national (sometimes subnational) level, out of which all firms arise, and in which all - though to varying extents - remain embedded. The implication of the GCC framework seems to be that firms are principally reflexes of the way given commodity chains are organized and of the structural requirements this imposes on their operation in any given location. In this scheme of things firms appear to have little autonomy to develop relatively independent strategies (though this seems crucial for the prospects for sustained development). Additionally there appears to be little room for understanding where national and local differences in labour market organization, working conditions etc. come from. In our view these issues cannot be effectively theorized unless it is understood that inter-firm networks link societies which exhibit significant social and institutional variation, embody different welfare regimes and have different capacities for state economic management: in short, represent different forms of capitalism (cf. Boyer and Drache, 1996; Whitley, 1999; Coates, 2000).

As an emerging theory of development, however, the GCC perspective has much to recommend it. Not least, it has helped to spawn important empirical work on footwear, garments, electronics, horticulture, 
tourism and auto-components, for instance, and has provided the analytical rationale for what could become new policy initiatives from the International Labour Office (ILO). ${ }^{9}$ It carries forward the task of transcending the limitations of state-centred forms of analysis and in so doing highlights the restrictions on firm - and thus economic and social - development that arise from the structure of corporate power embedded in the intra and inter-firm networks which circle the globe. By helping to show that the capacities to generate value are asymmetrically distributed because of the structure of GCCs, the perspective points to the existence of new forms of 'dependent development', as well as to possible ways of transcending those constraints.

\section{Network concepts}

A chain maps the vertical sequence of events leading to the delivery, consumption and maintenance of goods and services - recognising that various value chains often share common economic actors and are dynamic in that they are reused and reconfigured on an ongoing basis - while a network highlights the nature and extent of the inter-firm relationships that bind sets of firms into larger economic groupings.

(Sturgeon, 2001: 10)

A major weakness of the 'chain' approach is its conceptualization of production and distribution processes as being essentially vertical and linear. In fact, such processes are better conceptualized as being highly complex network structures in which there are intricate links - horizontal, diagonal, as well as vertical - forming multi-dimensional, multi-layered lattices of economic activity. For that reason, an explicitly relational, network-focused approach promises to offer a better understanding of production systems.

One such approach is actor-network theory (ANT) which emphasizes the relationality of both objects and agency in heterogeneous networks ('relational materiality'), pointing out that entities in networks are shaped by, and can only be understood through, their relations and connectivity to other entities (Law, 1999:4). For the study of global production networks, this means that space and distance have to be seen not in absolute, Euclidean terms, but as 'spatial fields' and relational scopes of influence, power and connectivity (Harvey, 1969; Murdoch, 1998). Among other things, this has important implications for the conceptualization of the 'global' and of 'globalization'.10

Another important aspect of ANT is its rejection of artificial dualisms such as the traditional global-local and the structure-agency dichotomies. Finally, ANT conceptualizes networks as hybrid collectivities of human 
and non-human agents and thus allows the consideration of the important technological elements that underlie and influence economic activities. However, while ANT offers an interesting methodology, that has been adopted already for the study of globalization and production networks (see, for instance, Whatmore and Thorne, 1997), its contribution to the analysis of economic development is constrained by the fact that it lacks an appreciation of the structural preconditions and power relations that inevitably shape production networks (Dicken et al., 2001: 107).

One contribution with a direct affinity to our work is Dieter Ernst's version of the global production network. Developed contemporaneously, but independently of our work, ${ }^{11}$ Ernst conceives of a GPN as a particular kind of organizational innovation, namely one that:

combine(s) concentrated dispersion of the value chain across firm and national boundaries, with a parallel process of integration of hierarchical layers of network participants.

(Ernst and Kim, 2001: 1)

The fundamental rationale for firms to establish GPNs of this nature is supposedly to access flexible, specialized suppliers in lower-cost locations. The GPN is seen to supersede the transnational corporation as the most effective form of industrial organization, a shift that has emerged in response to three constituent processes of globalization; namely, the ascendancy of liberalization policies, the rapid up-take of information and communication technologies, and the onset of 'global' competition.

The empirical evidence used to illustrate this alleged wholesale shift in industrial organization is anecdotal and almost exclusively drawn from the electronics and information technology industries. Consequently, rather than having developed an explanatory category of general relevance, Ernst has tended to highlight only one particular form of industrial organization; and one, at that, which seems to be drawn from a sectorally narrow range. Ernst's work is particularly helpful, however, in that he highlights a number of key problems that have hindered previous research in this area.

First, he criticizes the tendency to focus narrowly on the role of key 'flagship' firms within GPNs at the expense of attention to network suppliers that are more than one stage removed from the flagship. Second, he notes that in mapping the dispersion of production units, research has often overlooked the wide range of service functions (from design to marketing and beyond) that are crucial to the viability of GPNs. Third, Ernst notes a pre-occupation with formal R\&D and technology transfers, which may preclude an appreciation of the importance of diffusion of less codified forms of knowledge. Indeed, much of Ernst's research under the GPN banner has been concerned with the potential for different forms of knowledge (which he variously terms 'embrained', 'embedded', 
'encultured') to be diffused from GPNs in developing country locations and thereby stimulate local industrial upgrading (see, for example, Ernst, 2000).

\section{GLOBAL PRODUCTION NETWORKS}

The concept of the global production network (GPN) developed in the remainder of this article draws on many aspects of the work outlined in the preceding section. In particular, it builds upon the work of Gereffi and his collaborators but takes seriously the criticisms that have been levelled against it. Concomitantly, the framework aims to provide a more generally applicable conceptualisation of the GPN than that of Ernst. Before we elaborate the nature of the GPN, however, we need to explain our preferences for the terms 'production' rather than 'commodity' and 'network' rather than 'chain'. We also need to indicate our understanding of 'global'.

In contemporary usage the term 'commodity' generally connotes standardized products and with that, the fixity of their production in time and space. While this remains the reality of some forms of productive activity and products (some agriculture, some heavy industry and minerals extraction, for instance), it clearly does not capture adequately the post-fordist forms of activity that characterise many of the industries that the GCCs framework, for instance, was designed to analyse. More importantly, perhaps, our preference for a discourse of 'production' places the analytic emphasis on the social processes involved in producing goods and services and reproducing knowledge, capital and labour power. Notwithstanding Marx's definitive deconstruction and interrogation of the commodity (in Part I of the first volume of Capital), the discourse of commodities has long been captured by orthodox economics of whatever paradigm. As a consequence, it has transmuted into a reified language shorn of its social content. There is a need, therefore, to refocus attention on the social circumstances under which commodities are produced and consumed and thus avoid the ever-present danger of slipping into a perception of commodities as de-humanized building blocks involved in the making of other commodities.

The metaphor of the chain gives the impression of an essentially linear process of activities that ultimately result in a final commodity rather than one in which the flows of materials, semi-finished products, design, production, financial and marketing services are organized vertically, horizontally and diagonally in complex and dynamic configurations. Additionally, the chain metaphor - consistent with a commodity discourse - seems to have difficulties incorporating due attention to the issues of the reproduction of labour power etc. Furthermore, the chain metaphor works against the possibility of conceiving of the individual 
firms incorporated into a production system has having room for autonomous action within that system, in spite of the fact that such autonomy is central to the possibilities for industrial upgrading and thus sustained economic development. As a consequence of these difficulties, we find a discourse of networks to be more inclusive, empirically adequate and thus more analytically fertile.

Adoption of a network discourse also delivers other potential benefits. In particular, as long as 'production' is couched broadly to include intermediate and final markets and as long as the dynamics of power and knowledge between actors and institutions are understood in a multidirectional and non-deterministic fashion, then the GPN framework allows for far greater complexity and geographical variation in producerconsumer relations than the GCC approach, for instance, has so far achieved. Specifically, it should facilitate our ability to reveal how certain key knowledges 'circulate' between producers, consumers and intermediaries, rather than moving in a uni-directional manner, a key insight of the expanding literature on 'commodity cultures' (e.g. Cook and Crang, 1996; Jackson, 1999). Moreover, this approach should also allow more complex social geographies to be revealed, in the sense that agents in a variety of locations can be seen to combine to influence the production process. ${ }^{12}$

Finally, while it is now fashionable to term 'global', phenomena and practices that until recently would have been more likely to be termed 'international' or 'transnational', our adoption of the former term is driven by our concerns with analytical precision. Specifically, the terms 'international' and 'transnational' derive from essentially state-centric discourses. Thus while they incorporate notions of cross-border activity of many sorts, they do not adequately express the way in which non place-specific processes penetrate and transform place-specific ones, and vice versa. They do not, therefore, help to deliver the imaginative sensibilities necessary to grasp the dialectics of global-local relations that are now a pre-condition for the analysis of economic globalization and its asymmetric consequences.

The global production network as proposed here, is a conceptual framework that is capable of grasping the global, regional and local economic and social dimensions of the processes involved in many (though by no means all) forms of economic globalization. ${ }^{13}$ Production networks - the nexus of interconnected functions and operations through which goods and services are produced, distributed and consumed have become both organizationally more complex and also increasingly global in their geographic extent. Such networks not only integrate firms (and parts of firms) into structures which blur traditional organizational boundaries - through the development of diverse forms of equity and non-equity relationships - but also integrate national economies (or parts 
of such economies) in ways which have enormous implications for their well-being. At the same time, the precise nature and articulation of firm-centred production networks are deeply influenced by the concrete socio-political contexts within which they are embedded. The process is especially complex because while the latter are essentially territorially specific (primarily, though not exclusively, at the level of the nation-state) the production networks themselves are not. They 'cut through' state boundaries in highly differentiated ways, influenced in part by regulatory and non-regulatory barriers and local sociocultural conditions, to create structures which are 'discontinuously territorial' ${ }^{14}$

The GPN framework explicitly recognizes that:

- firms, governments and other economic actors from different societies sometimes have different priorities vis-à-vis profitability, growth, economic development etc. (as was made clear, for instance, in the commentary surrounding the East Asian crisis; e.g. Chang, 1998 and Henderson, 1999) and consequently the production network's implications for firm and economic development at each spatial location cannot be 'read-off' from the logic of the network's organisation and the distribution of corporate power within it. The GPN perspective, in other words, accords a degree of relative autonomy to domestic firms, governments and other economic actors (e.g. trade unions, where relevant) whose actions potentially have significant implications for the economic and social outcomes of the networks in the locations they incorporate.

- input-output structures within the networks are centrally important, not least because it is these that constitute the sites where value is generated and where the enormous variations in working conditions that exist around the world, are delivered. Consequently any work on intra and inter-firm networks must pay significant attention to these structures and their consequences;

- an understanding of the 'territoriality' of production networks namely, how they constitute and are re-constituted by the economic, social and political arrangements of the places they inhabit - is central to an analysis of the prospects for development at the local level.

- the distinction between 'producer-driver' and 'buyer-driven' networks is more fluid than Gereffi's work allows for, with combinations of both in the same product areas, and indeed in some cases (e.g. auto components and consumer electronics) the same sector; and

- in some sectors (pharmaceuticals and some electronics for example) technological alliances and licensing agreements are forms of interfirm association that may have significant developmental implications. Consequently they require attention in their own right. 
Methodologically, then, the GPN perspective directs attention to:

- the networks of firms involved in $R \& D$, design, production and marketing of a given product, and how these are organized globally and regionally;

- the distribution of corporate power within those networks, and changes therein;

- the significance of labour and the processes of value creation and transfer; and

- the institutions - particularly government agencies, but also in some cases trade unions, employer associations and NGOs - that influence firm strategy in the particular locations absorbed into the production chain;

- the implications of all of these for technological upgrading, valueadding and capturing, economic prosperity etc. for the various firms and societies absorbed into the chains.

More specifically the components of the GPN framework can be disaggregated - for purposes of elaboration - by reference to Figure 1. While we elaborate these components below, it is worth noting here our view of 'technology' in the schema. While some contributions recognize the central role of technological change and information and communication technology (ICT) in shaping and transforming global networks, we exclude 'technology' as a separate category. Instead, ICT is rather seen as an inherent element of GPNs, underlying the development and maintenance of network connections. Technology, as one of globalization's drivers, influences the processes of value creation in different places, as well as transforming the means by which power is exercised. Additionally, it affects the agents' possibilities of embedding in, and disembedding from, particular networks and territories.

A similar view is taken of the notion of spatiality. Specific spatial configurations are an inherent characteristic of all networks; each GPN can be mapped by 'placing' its agents and sketching their mutual connections. By the same token, every form of embeddedness always has an intrinsic spatial character.

There are, however, other aspects of spatiality to be considered. Firstly there is the issue of scalarity. All GPNs have to be regarded as multiscalar, ranging from the local and regional to the national and global and back again. ${ }^{15}$ Such multi-scalar networks are built-up and transformed over time by a multiplicity of agents with asymmetrical influence and power. This leads to another important facet of spatiality; namely the boundedness of network-based activities, for instance within the political space of the national (or in federal contexts, sub-national) state. Whereas business agents are able to transcend political or other borders (cultural, for instance) between territories, most of the non-business 


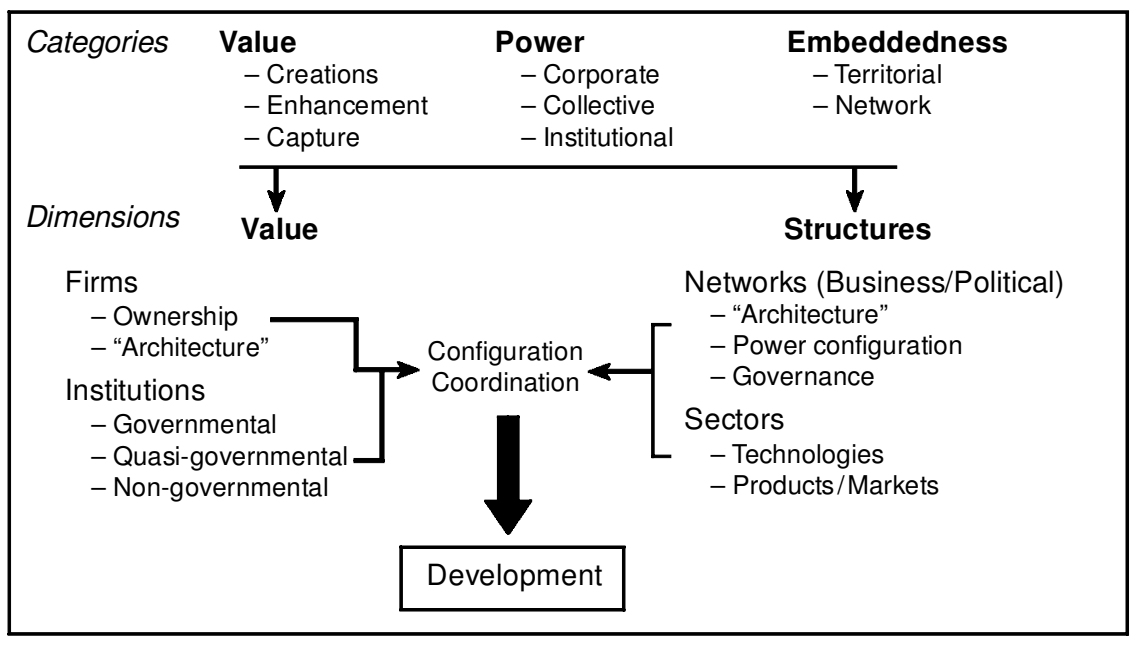

Figure 1 A framework for GPN analysis

institutions are bounded - and thus restricted - by their spatial contexts at different geographic scales. This, of course, has various implications for development, especially in terms of the distribution of power and value creation and capture.

\section{Conceptual categories}

There are three principal elements on which the architecture of the GPN framework is raised. The first of these is:

Value: by 'value' we mean both Marxian notions of surplus value and more orthodox ones associated with economic rent. Thus we are interested in the following matters.

- The initial creation of value within each of the firms incorporated into a given GPN. The significant issues here include the conditions under which labour power is converted into actual labour through the labour process; and the possibilities for generating various forms of rent. In the former the issues of employment, skill, working conditions and production technology are important as well as the circumstances under which they are reproduced (hence connecting these issues to broader social and institutional questions). In the latter (see Kaplinsky, 1998; Gereffi, 1999b) the issues are whether a given firm can generate rents from (a) an asymmetric access to key product and process 
technologies ('technological rents'); (b) from particular organizational and managerial skills such as 'just-in-time' production techniques and 'total quality control' etc. ('organizational rents'); (c) various inter-firm relationships that may involve the management of production linkages with other firms, the development of strategic alliances, or the management of relations with clusters of small and medium sized enterprises ('relational rents'); or (d) from establishing brand-name prominence in major markets ('brand rents'). In certain sectors and circumstances (e) additional rents may accrue to some firms as a consequence of the product scarcities created by protectionist trade policies ('trade-policy rents'), though this is another issue that connects questions of value creation to the institutional contexts (national and international in this case) within which firms operate.

- The circumstances under which value can be enhanced. The issues involved here include: (a) the nature and extent of technology transfers both from within and without the given production network; (b) the extent to which lead and other major firms within the network engage with supplier and subcontractors to improve the quality and technological sophistication of their products; (c) as a consequence, whether demands for skill in given labour processes increase over time; (d) whether local firms can begin to create organizational, relational and brand rents of their own. In all of these cases, the national institutional influences to which the firms are subject (government agencies, trade unions, employer associations, for instance) may be decisive for the possibilities of value enhancement. ${ }^{16}$

- The possibilities that exist for value to be captured. It is one thing for value to be created and enhanced in given locations, but it may be quite another for it to be captured for the benefit of those locations. The pertinent issues here partly involve (a) matters of government policy, but they also involve (b) questions of firm ownership and (c) the nature of corporate governance in given national contexts. In the first case, the nature of property rights and thus laws governing ownership structures and the repatriation of profits can be important, while in the second the extent to which firms are totally foreign owned, totally domestically owned, or involve shared equity as in joint-venture arrangements, continues to be decisive as a long tradition in the political economy of development has argued and recent experience in Britain, for instance, has underlined. ${ }^{17}$ In the third case, the extent to which corporate governance is founded on stakeholder principles, rather than on shareholder dominance (and required by legal statute) can have important consequences for whether value generated in a given location is retained there and indeed used to the benefit of the commonweal. ${ }^{18}$ The issue of value capture, then, underlines the significance of the national form of capitalism - and thus matters of 
expectations, rights and obligations - for questions of economic and social development.

Power: the source of power within the GPNs and the ways in which it is exercised is decisive for value enhancement and capture and thus for the prospects for development and prosperity. ${ }^{19}$ There are three forms of power that are significant here.

- Corporate power. Here we have in mind the extent to which the lead firm in the GPN has the capacity to influence decisions and resource allocations - vis-à-vis other firms in the network - decisively and consistently in its own interests. Our adoption of a network discourse implies a rejection of a zero-sum conception of power in that lead firms rarely, if ever, have a monopoly on corporate power. Rather, while power is usually asymmetrically distributed in production networks, lesser firms sometimes (and for contingent reasons) have sufficient autonomy to develop and exercise their own strategies for upgrading their operations etc. Additionally, and at least in principle, lesser firms incorporated into networks have the possibility of combining with other lesser firms to improve their collective situation within the GPN (as when SME clusters constituted as industrial districts are incorporated into GPNs). ${ }^{20}$

- Institutional power. Our reference here is to the exercise of power by: (a) the national and local state (in the latter case where the national state is constituted as a federal polity); (b) international inter-state agencies ranging from the increasingly integrated European Union on the one hand through to looser confederations such as ASEAN or NAFTA on the other; (c) the 'Bretton Woods' institutions (International Monetary Fund, World Bank) and the World Trade Organisation; (d) the various UN agencies (particularly the ILO); and (e) the international credit rating agencies (Moodys, Standard and Poor etc.) which exercise a unique form of private institutional power. The capacity to exercise power to influence the investment and other decisions of lead companies and other firms integrated into GPNs is inevitably asymmetric and varies both within and between these five categories. Thus with regard to national states, some of those in East Asia (particularly South Korea and Taiwan, but more recently China) have been perceived in recent decades as being among the most capable of influencing private companies in the interests of industrialization and development (among an enormous literature see Wade, 1990 and Henderson, 1993) while states as disparate as those of Britain and Indonesia have been far less able to do so. ${ }^{21}$ The power of the interstate agencies is potentially considerable - particularly in the case of the EU - though elsewhere it remains weakly developed. The power of the Bretton Woods institutions, while it can be considerable, is 
exercised indirectly and impacts on companies, workforces and communities via the economic and social policies that national governments are obliged to implement. The power of the UN agencies is of much less significance than any of the others in that its influence on firms is not merely indirect, but it is also only moral and advisory. The significance of the credit rating agencies is potentially considerable, both directly for many lead companies and indirectly via their credit risk assessments of national governments. However, as yet we know little of the ways in which their influence is exercised (but see Sassen, 1999).

- Collective power. By this form of power we understand the actions of collective agents who seek to influence companies at particular locations in GPNs, their respective governments and sometimes international agencies (most recently the IMF and WTO in particular). Examples of such collective agents include trade unions, employers associations, and organizations that advance particular economic interests (e.g. of small businesses), NGOs concerned with human rights, environmental issues etc. These agencies may be nationally or locally specific, or they may be internationally organized as with some trade unions (e.g. the International Metal Workers) or human rights organizations (e.g. Amnesty International). In most circumstances where such agencies are engaged, they attempt to exercise countervailing power either directly on particular firms or groups of firms within given networks or indirectly on national governments or international agencies.

Embeddedness: GPNs do not only connect firms functionally and territorially but also they connect aspects of the social and spatial arrangements in which those firms are embedded and which influence their strategies and the values, priorities and expectations of managers, workers and communities alike. The ways in which the different agents establish and perform their connections to others and the specifics of embedding and disembedding processes are to a certain extent based upon the 'heritage' and origin of these agents. Firms - be they TNCs or smaller local enterprises - arise from, and continue to be influenced by, the institutional fabrics and social and cultural contexts of particular forms of capitalism (or in the case of Eastern Europe, China etc. prior to the 1980s, particular forms of state socialism) in their countries of origin. While the nature of education, training and labour systems and the sources and organization of corporate finance are important, of particular significance for firm development, priorities and strategies are the nature of state policy and the legal framework (cf. Zysman, 1983; Hutton, 1995; Whitley, 1999).

Local companies that have emerged from particular social and institutional contexts evolve over time on the bases of trajectories that are 
in part a reflection of these contexts. As many scholars have pointed out with regard to the former state socialist societies of Eastern Europe, these trajectories are 'path dependent' and thus to some extent historically constrained (for instance, Stark, 1992; Hausner et al., 1995; Czaban and Henderson, 1998). While it is important to recognize that such constraints are not immutable and that their influence may be waning - not least because of globalization - it is also important to acknowledge that some lead firms when investing overseas may carry the institutional 'baggage' of their home bases with them. But others might also tend to operate at or near the lowest common denominator that domestic policies and legal frameworks will allow.22

Among the different dimensions and aspects of embeddedness, ${ }^{23}$ there are two related forms of firm and network embeddedness that are of interest here. The first form, territorial, deals with the various GPN firms' 'anchoring' in different places (from the nation state to the local level), which affects the prospects for the development of these locations. The second form, network embeddedness, refers to the network structure, the degree of connectivity within a GPN, the stability of its agents' relations and the importance of the network for the participants. Both forms, of course, are the result of essentially social and spatial processes of 'embedding'.

- Territorial embeddeness. GPNs do not merely locate in particular places. They may become embedded there in the sense that they absorb, and in some cases become constrained, by the economic activities and social dynamics that already exist in those places. One example here is the way in which the GPNs of particular lead firms may take advantage of clusters of small and medium enterprises (with their decisively important social networks and local labour markets) that pre-date the establishment of subcontracting or subsidiary operations by such firms. Moreover, the location of lead firms in particular places might generate a new local or regional network of economic and social relations, involving existing firms as well as attracting new ones. Embeddedness, then, becomes a key element in regional economic growth and in capturing global opportunities (Harrison, 1992; Amin and Thrift, 1994). ${ }^{24}$ The resulting advantages in terms of value creation etc. may result in spatial 'lock-in' for those firms with knockon implications for other parts of that firm's GPN (see Grabher, 1993 and Scott, 1998). Similarly, national and local government policies (training programmes, tax advantages etc.) may function to embed particular parts of the GPN in particular cities or regions, in order to support the formation of new nodes in global networks, or what Hein (2000) describes as 'new islands of an archipelago economy'. But the positive effects of embeddedness in a particular place cannot be taken for granted over time. For example, once a lead firm cuts its ties within 
a region (for instance, by disinvestment or plant closure), a process of disembedding takes place (Pike et al., 2000:60-1), potentially undermining the previous base for economic growth and value capture. From a development point of view, then, the mode of territorial embeddeness or the degree of a GPN firm's commitment to a particular location, is an important factor for value creation, enhancement and capture.

- Network embeddeness. GPNs are characterized not only by their territorial embeddedness, but also by the connections between network members regardless of their country of origin or local anchoring in particular places. It is most notably the 'architecture', durability and stability of these relations, both formal and informal, which determines the agents' individual network embeddedness (actor-network embeddedness) as well as the structure and evolution of the GPN as a whole. While the former refers to an individual's or firm's relationships with other actors, the latter consists not only of business agents involved in the production of a particular good or service, but also takes the broader institutional networks including non-business agents (e.g. government and non-government organizations) into account. Network embeddedness can be regarded as the product of a process of trust building between network agents, which is important for successful and stable relationships. Even within intra-firm networks, where the relationships are structured by ownership integration and control, trust between the different firm units and the different stakeholders involved might be a crucial factor, such as in the case of joint ventures (Yeung, 1998).

\section{Conceptual dimensions}

The categories sketched above are 'energized' and 'live' through a number of conceptual dimensions. These constitute the frameworks through which value is created, power exercised or institutional embeddedness etc. given concrete effect in terms of particular initiatives and policies. There are four broad dimensions that are of significance.

\section{Firms}

One firm is clearly not the same as another. Firms, even within the same sector, differ in terms of their strategic priorities, their attitudes to labour relations, the nature of their relations with suppliers etc. As a consequence one would expect that while there may be similarities between the ways in which firms in the same sector operate (generate value, exercise their power over suppliers etc.), there will still be important firmspecific differences, not least in terms of the locations where lead firms decide to invest or establish supplier and subcontractor connections. 
These differences may stem from the nature of ownership (equity arrangements, and/or 'nationality'), managerial whim or they may derive from values embodied in the firm's evolution. ${ }^{25}$ Whatever the source of these differences it is likely that they have implications for the ways in which their GPNs are constructed (if they are lead firms) or for the ways in which they participate (seek to develop and exercise autonomy, for instance) in other firm's GPNs (if they are suppliers and subcontractors).

\section{Sectors}

While GPNs have characteristics that are firm-specific, firms that operate in the same sector are likely to create GPNs that have some degree of similarity. The reasons for this are that similar technologies, products and market constraints are likely to lead to similar ways of creating competitive advantage and thus broadly similar GPN architectures. Thus, for our purposes, a sector need to be defined by criteria other than mere statistical classification. Besides being a unique structure of competition and technology, firms in the same economic sector usually share a common 'language' and a particular communication structure specific to that sector (Hess, 1998). A sector not only includes a range of companies, from the sector's leading producers to suppliers of different elements, including service functions, but its governance structure is often complemented by purpose-built organizations, such as industrial pressure groups (for instance, employer and labour associations), vocational training institutions or others. These sectoral particularities create sectorspecific regulational environments, were particular issues are addressed by government policies at different scales. Examples of these include the supra-national multi-fibre-agreement for the textiles and clothing sector and national 'sector' policies to foster innovation and competitiveness (as is the case of some Asian countries' automobile and electronics industry policies).

\section{Networks}

It is within the various networks that particular issues of governance arise. As the ways in which power is mobilized and exercised is likely to vary for a combination of firm and sector-specific reasons, it is reasonable to expect that the architecture of governance is likely to exhibit considerable variation. As a consequence there is likely to be significant variation, for instance, in the extent to which secondary firms in a given network are capable of exercising a degree of autonomy that would allow them to move into higher value-added activities with their more positive implications for economic development. Pending much more research that is open to such variations, it is premature to move towards a conceptual closure of network governance structures. 


\section{Institutions}

In principle the institutional arrangements impact both locally and globally on the GPNs. ${ }^{26}$ they can be of considerable importance in the generation of value locally, in its enhancement and in its capture. Additionally they can be of utmost significance in setting standards (including the moral tone) for labour relations, working conditions and wage levels. They are, in other words, central to the question of whether GPNs can deliver sustained economic and social development in the locations they incorporate. It is important to recognize, of course, that the consequences which institutions have for GPNs and their local and international operations and implications, can be positive or negative. In the latter case the institutional fabric of post-socialist Russia, for instance, seems to be a case in point for all but criminal networks (see Castells, 2000b: chapters 1 and 3) as are some of the recent policy decisions of the IMF (in relation to the East Asian crisis, for instance) and WTO.

\section{GPN categories and dimensions: a stylised example}

As an indication of how GPNs might be visualized and analysed, we develop below a mapping technique that allows us to highlight and compare their main elements and linkages. We apply this to a stylised example ${ }^{27}$ in order to underline the potential significance of the GPN framework for the analysis of inter-organizational connections, and their relation to economic development in the regions, states and localities affected by the GPN in question.

In Figure 2, we have sketched a GPN operating in four 'regions' and composed of different types of firms and involving organizations of various scopes, from local influence to global power. In each of the regions, be they geographic arenas (such as Eastern Europe), economic blocs (such as the European Union), nation states or sub-national territories, value is created and captured, but to varying extents. Region A, for example, shows high degrees of value generation and capture without containing much of the network's material flows. This could be the case for a lead firm with strong R\&D activities, design, marketing and other services retained in its home country, while dispersing its lower value-added production processes to other countries. In contrast, Region $C$ is a location for value creation, but it is unable to capture much of it as a result, for instance, of external ownership of many first and second tier suppliers there and the profit transfers to the respective corporate headquarters outside of the region.

Two examples of low value creation are Regions B and D. The latter shows little or no capacity to capture whatever value that is being created within the region, as can often be the case in pure 'branch plant' circumstances. Neither the low value added in terms of products or technology, 


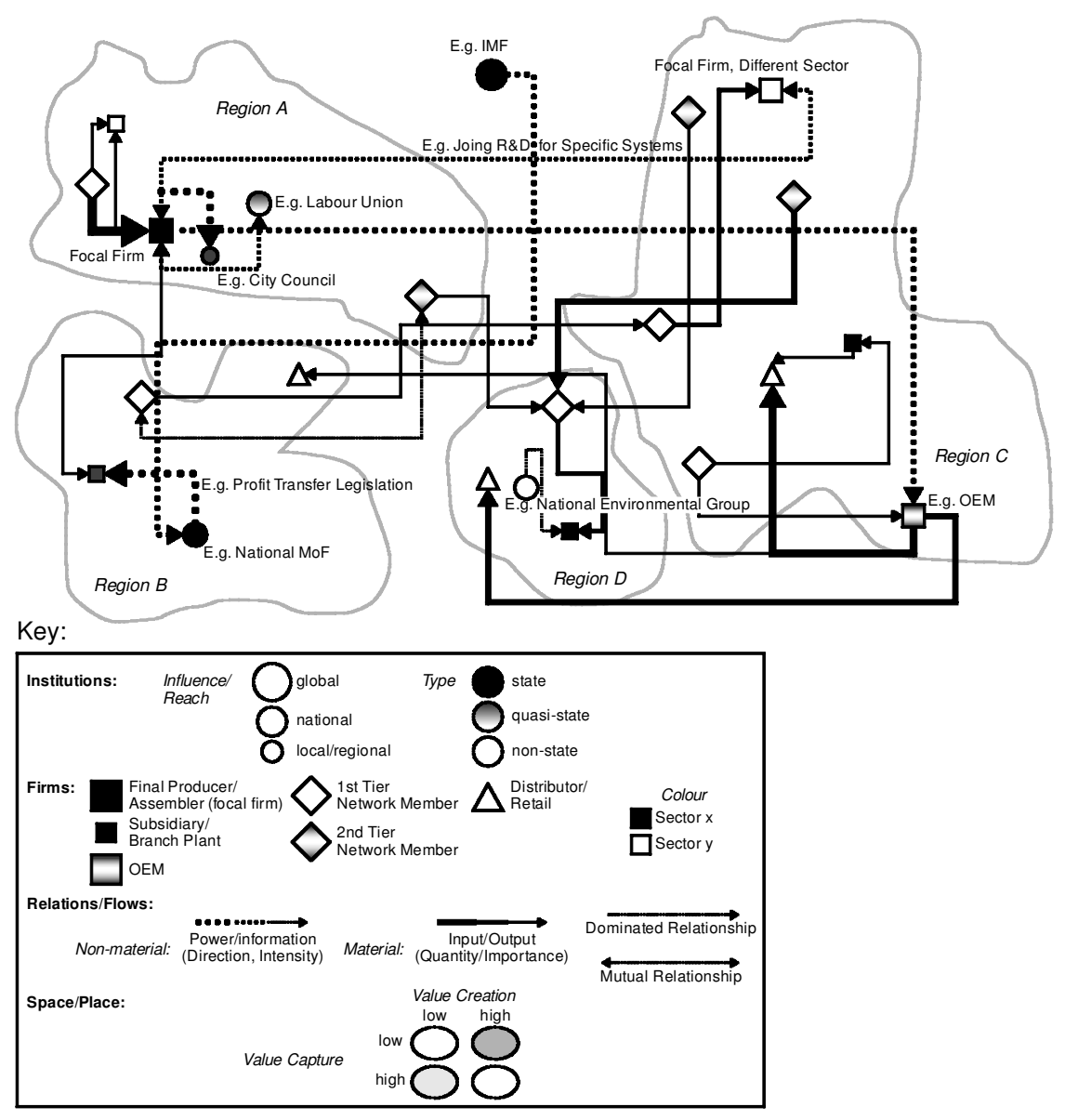

Figure 2 Mapping global production networks - a stylised example

nor the enhancement of skills (value in the form of knowledge), is unusual in this type of situation. The positive implications for development of being integrated in a GPN, under such circumstances, therefore, are rather limited, In Region B, on the other hand, though not much value is created, most of it is captured within the region. In this case, the ability to capture value is enhanced by the non-firm institutions, shown in Figure 1. This ability, of course, strongly relates to questions of power and its distribution.

The power exercised within the GPN can be shown as non-material flows between different agents (firms as well as other organizations). The 
value generation and capture process in Region $B$, for instance, is heavily determined by the power of global institutions (e.g. IMF) and national government agencies, here represented as the ministry of finance (MoF) influencing the profit transfers of foreign owned subsidiaries. An actual case in point would be the GPN of foreign car assemblers in China, where government power is used to influence the localization of production and therefore the value generation and capture process, including aspects of employment, skills and technology transfer.

The corporate power of some firms over their regional environment, on the other hand, is exemplified by Region A's lead firm affecting the local administration, as shown in Figure 2, while collective power is exercised by the labour union. There are plenty of examples where a company or a group of firms are able to shape the institutional and regional environment in its favour, especially on the local and national levels, as in economically weak regions eager to attract or retain external investment.

The territorial embeddedness of the network under consideration is not immediately educible, but can be represented by the density and intensity of local/regional or national connections between the different agents. Firms and organizations in Region D, for instance, have only few and rather weak relations with each other. There, then, territorial embeddedness is limited. Linkages to other agents outside the region, on the other hand, are comparatively strong, indicating a high degree of network embeddedness.

In sum, the technique of mapping the GPN demonstrated here provides the possibility of visualizing the economic and social agents as well as highlighting the structural and spatial dimensions of networks, sectors, and the linkages between them. It allows us to visualize the GPN's implications for development in different places within the GPNs' territorial reach, and the main agents responsible for these implications. What cannot be shown, of course, is the evolution of the GPN over time (path dependency) and structural preconditions shaping it (such as different national capitalisms or national modes of regulation). Nevertheless, what we have here is a scale-transcending model of global production networks which provides a sense of their likely implications for economic and social development.

\section{CONCLUSION}

In this article we have outlined a conceptual framework for mapping and analysing certain aspects of economic globalization - those related to production and consumption - and their developmental consequences. In so doing we have foregrounded the ways in which companies organize and control their global operations, the ways in which they are (or 
can be) influenced by states, trade unions, NGOs and other institutions in particular locations and the implications that the resulting combinations of agents and processes might have for industrial upgrading, higher valued added etc. and ultimately for the prospects of poverty reduction and/or generalized prosperity in those locations.

The framework we have proposed - that of the global production network - is an explicit attempt to break with state-centric conceptualisations on the one hand and significantly extend the analytic and policy utility of cognate formulations on the other. The proof of success, however, will depend on whether the GPN framework stimulates research that delivers analyses that are both empirically and theoretically richer than at present. More importantly, however, it will depend on whether the framework helps to produce research that contributes more effectively to the task of improving the human condition in the age of economic and geo-political turbulence in which we now exist.

\section{ACKNOWLEDGEMENTS}

This article draws on work conducted under the auspices of the Economic and Social Research Council project, Making the Connections: Global Production Networks in Europe and East Asia (Grant \# R 000 238535). We are grateful to the ESRC for their support and to Dieter Ernst, John Humphrey, Alisdair Rogers, three anonymous referees and the participants at the Annual Conference of the Global Studies Association (Manchester, July 2001) for their comments on an earlier version.

\section{NOTES}

1 For the purposes of this article, our intellectual engagement is largely with contributions to the political economy of development be they in 'sociological', 'economic', 'geographic' or 'political science' guises.

2 We have in mind here the arguments of the supposed panacea of 'free' markets as development tools, on the one hand, through to the stress on state industrial initiatives on the other, as well as those that view the statemarket relation as symbiotic for development purposes. In all of these cases, however, the analytical weight tends to be placed on the nature and application of state economic policy (cf. Evans, 1992).

3 The few notable monographs here (such as Gereffi, 1983; Henderson, 1989; Doner, 1991; Sklair, 1993) only serve to underline the general rule.

4 We do not mean to deny the relevance of some state-centric contributions to the analysis of globalization and its problems and how the latter might be resolved. Some of the work on the East Asian crisis, for instance (e.g. Chang, 1998; Henderson, 1999; Weiss, 1999) are cases in point.

5 See, for example, Gereffi (1995, 1999a); Gereffi and Korzeniewicz (1994); Sklair (1995) and the IDS Bulletin $(32 / 3,2001)$ which focuses entirely on global value chains. 
6 On the former see, for instance, Jessop's (2001) collection of some of the seminal contributions. On the latter see Storper and Salais (1997, particularly chapter 10).

7 Hardly any work has been done, for instance, on households, states and the reproduction of labour power from within a GCCs perspective.

8 See, for instance, the work on the Brazilian 'reserved market' for personal computers (Evans, 1986; Schmitz and Hewitt, 1992).

9 See, for instance, the essays collected in Gereffi and Korzeniewicz (1994) and the special issue of the IDS Bulletin $(32 / 3,2001)$. See also Clancy (1998); Dolan and Humphrey (2000); Bonacich and Appelbaum (2000) and Kaplinsky (2000) among others. The ILO's research institute, the International Institute of Labour Studies, sponsored a programme on 'global commodity chains' in the late 1990s. The continuing media attention to the exploitative working conditions evident in the supplier companies integrated into the chains of the likes of Nike and Gap, for instance, underlines the utility of the GCC framework for agencies such as the ILO.

10 Specifically it implies rejection of the term 'global' as a simplistic geographical construct (see our later discussion). Similarly economic 'globalization', comes to refer to the extension of functionally integrated (and thus socially relational) economic activities across national boundaries (cf. Dicken, 1998: 5). The implication of this for the conceptualisation of GPNs is that they come to be seen as dynamic typologies which potentially change shape and scope over time.

11 Though he had previously worked with the notion of the 'international production network', Ernst first used the term 'global production network' in a conference paper of 1999 (Ernst, 1999). Our first attempt to elaborate a GPN framework appeared in a research proposal that same year (Dicken and Henderson, 1999).

12 See, for instance, Hughes' (2000) study of the cut-flower trade.

13 It is unlikely to be of particular help, for instance, for the analysis of some forms of finance capital such as bank loans and portfolio investment.

14 For a discussion of regional politics and production networks, see Cabus and Hess (2000).

15 In other works, a continuum of scales (see Swyngedouw, 1997; Dicken and Malmberg, 2001).

16 There is a growing literature that addresses these concerns with respect to differing 'qualities' of foreign direct investment. See, for instance, Turok (1993, Amin et al. (1994) and Young et al. (1994).

17 We have in mind the continuing dis-investment in British subsidiaries (with knock-on effects for local suppliers) by foreign companies. Since 1998 these have included at a minimum: Siemens, Samsung, LG and Motorola (in electronics), BMW, Ford and General Motors (in automobiles) and Corus (steel).

18 Germany, on the one hand, and Britain and the USA, on the other, constitute polar opposites in this sense. In the latter, shareholders have supreme power over the disposal of profits and assets, while in the former owners are obliged to consider the interests of other stakeholders and the workforce in particular (Lane, 1989). Indeed in Germany, property holders have a constitutional obligation to exercise their rights in the interests of the public good (Hutton, 2001).

19 Although not theorized in terms of power, Humphrey and Schmidt's (2001) discussion of the governance structures of 'value chains' is an important complement, at this point, to our work. 
20 Castells develops ideas similar to these with regard to the exercise of economic and foreign policy by national states absorbed into 'network states' (of which the European Union is the prototype). See Castells (2000b: chapter 5) and also Carnoy and Castells (2001).

21 This is obviously not the place to explain such discrepancies except to mark that the answers seem to lie in a combination of political will (or its absence) and differing institutional capacities for economic governance. For the British and Indonesian cases see Hutton (1995) and Hill (1996) respectively. For more general and theoretical accounts of the relation between state capacities and economic development see Evans (1995) and Evans and Rauch (1999).

22 Japanese companies, for instance, have never offered 'permanent employment' contracts to employees in their foreign subsidiaries. Similarly German companies, though required by German and EU legislation to consult extensively with employees before instituting redundancy programmes, have never done so in countries where such laws do not apply. Recent disinvestments in Britain by Siemens and BMW are cases in point.

23 As Oinas (1997), Markusen (1999) and Pike et al. (2000), among others, have pointed out, the notion of embeddedness still remains rather vague and therefore in need of conceptual improvement. However, its importance for the understanding of economic organization is widely acknowledged, even by critical voices (see for example, Sayer, 2000).

24 There is also a downside. The nature of local networks and socio-economic relations may under certain circumstances generate an inability to capture global opportunities and lead to regional economic downturn (Oinas, 1997: 26). Strong embeddedness, therefore, is not necessarily a 'good' or positive quality of networks or its agents.

25 Examples in Britain, for instance, include the ethical stance of such companies as the Co-operative Bank and the Body Shop.

26 From the perspective of actor-network theory, GPNs would themselves be institutions. However, this is not the position adopted here. Rather institutions are perceived as social and political formations - be they sub-national, national or international - with attendant histories, values and cultural practices which have consequences for how GPNs are formed and develop over time.

27 This example is generalized and therefore by no means comprehensive; real GPNs, of course, have far more linkages and agents than could be sketched here. For instance, due to graphic restrictions, the intra-firm network flows of the lead company are not shown in Figure 2.

\section{REFERENCES}

Amin, A. and Thrift, N. (1994) 'Holding down the global', in A. Amin and N. Thrift (eds), Globalization, Institutions, and Regional Development in Europe, Oxford: University Press, pp. 257-60.

Amin, A., Bradley, D., Howells, J., Tomaney, J. and Gentle, C. (1994) 'Regional incentives and the quality of mobile investment in the less favoured regions of the EC', Progress in Planning 41(1): 1-112.

Armstrong, W. and McGee, T.G. (1985) Theatres of Accumulation. New York: Methuen. 
Bonacich, E. and Appelbaum, R.P. (2000) Behind the Label: Inequality in the Los Angeles Garments Industry. Berkeley and Los Angeles: University of California Press.

Boyer, R. and Drache, D. (eds) (1996) States against Markets: The Limits of Globalization. London, Routledge.

Cabus, P. and Hess, M. (2000) 'Regional politics and economic patterns: "glocalisations" and the network enterprise', BELGEO 1: 79-101.

Carnoy, M. and Castells, M. (2001) 'Globalization, the knowledge society and the Network State: Poulantzas at the millenium', Global Networks 1(1): 1-18.

Castells, M. (2000a) The Rise of the Network Society (2 ${ }^{\text {nd }}$ Edition). Oxford: Blackwell.

Castells, M. (2000b) End of Millennium (2 ${ }^{\text {nd }}$ Edition). Oxford: Blackwell.

Coates, D. (2000) Models of Capitalism. Cambridge: Polity Press.

Chang, H-J. (1998) 'Korea: the misunderstood crisis', World Development 26(8): $1555-61$.

Clancy, M. (1998) 'Commodity chains, services and development: theory and preliminary evidence from the tourism industry', Review of International Political Economy 5(1): 122-48.

Cook, I. and Crang, P. (1996) 'The world on a plate: culinary culture, displacement and geographical knowledges', Journal of Material Culture 1: 131-53.

Czaban, L. and Henderson, J. (1998) 'Globalisation, institutional legacies and industrial transformation in Eastern Europe', Economy and Society 27(4): 585-613.

Dicken, P. (1998) Global Shift (3 ${ }^{\text {rd }}$ Edition). London: Paul Chapman.

Dicken, P. and Henderson, J. (1999) 'Making the connections: global production networks in Britain, East Asia and Eastern Europe'. A research proposal to the Economic and Social Research Council (July).

Dicken, P., Kelly, P.F., Olds, K. and Yeung, H. W-C (2001) 'Chains and networks, territories and scales: towards a relational framework for analysing the global economy', Global Networks 1(2): 89-112.

Dicken, P. and Malmberg, A. (2001) 'Firms in territories: a relational perspective', Economic Geography 77: 345-63.

Dolan, C. and Humphrey, J. (2000) 'Governance and trade in fresh vegetables: the impact of UK supermarkets on the African horticulture industry', Journal of Development Studies 37(2): 147-76.

Doner, R.F. (1991) Driving a Bargain. Berkeley and Los Angeles: University of California Press.

Ernst, D. (1999) 'Globalization and the changing geography of innovation systems. A policy perspective on global production networks', Paper presented at the Workshop on the Political Economy of Technology in Developing Countries, Brighton, October 8-9.

Ernst, D. (2000) 'Global production networks and the changing geography of innovation systems: implications for developing countries', East-West Centre Working Paper, 9, Honolulu.

Ernst, D. and Kim, L. (2001) 'Global production networks, knowledge diffusion and local capability formation: a conceptual framework', Paper presented at the Nelson \& Winter Conference, Aalborg, 12-15 June.

Evans, P. (1986) 'State, capital and the transformation of dependence: the Brazilian computer case', World Development 14(7): 791-808.

Evans, P. (1992) 'The state as problem and solution: predation, embedded autonomy and structural change', in S. Haggard and R. Kaufman (eds), The Politics of Economic Adjustment: International Constraints, Distributive Conflicts and the State, Princeton: Princeton University Press, pp. 139-81. 
Evans, P. (1995) Embedded Autonomy. Princeton: Princeton University Press.

Evans, P. and Rauch, J. (1999) 'Bureaucracy and growth: a cross-national analysis of the effects of "Weberian" state structures on economic growth', American Sociological Review 64(4): 748-65.

Fröbel, F., Heinrichs, J. and Kreye, O. (1980) The New International Division of Labour. Cambridge: Cambridge University Press.

Gereffi, G. (1983) The Pharmaceutical Industry and Dependency in the Third World. Princeton: Princeton University Press.

Gereffi, G. (1994) 'The organisation of buyer-driven global commodity chains: how US retailers shape overseas production networks', in G. Gereffi and M. Korzeniewicz (eds), Commodity Chains and Global Development. Westport: Praeger, pp. 95-122.

Gereffi, G. (1995) 'Global production systems and third world development', in B. Stallings (ed.), Global Change, Regional Response. New York: Cambridge University Press, pp. 100-42.

Gereffi, G. (1999a) 'International trade and industrial upgrading in the apparel commodity chain', Journal of International Economics 48(1): 37-70.

Gereffi, G. (1999b) 'A commodity chains framework for analysing global industries', mimeo, Department of Sociology, Duke University.

Gereffi, G. and Korzeniewicz, M. (eds) (1994) Commodity Chains and Global Capitalism. Westport: Praeger.

Grabher, G. (1993) 'The weakness of strong ties: the lock-in of regional development in the Ruhr area', in G. Graher (ed.), The Embedded Firm: On the Socio-Economics of Inter-firm Relations. London: Routledge, pp. 255-78.

Harrison, B. (1992) 'Industrial districts: old wine in new bottles?', Regional Studies 26: 469-83.

Harvey, D. (1969) Explanation in Geography. London: Edward Arnold.

Hausner, J., Jessop, B. and Nielsen, K. (eds) (1995) Strategic Choice and Path Dependency in Post-Socialism. Aldershot: Edward Elgar.

Hein, W. (2000) 'Die Ökonomie des Archipels und das versunkene Land', E+Z, 41(11): 304-7.

Henderson, J. (1989) The Globalisation of High Technology Production. London: Routledge.

Henderson, J. (1993) 'The role of the state in the economic transformation of East Asia', in C. Dixon and D. Drakakis-Smith (eds), Economic and Social Development in Pacific Asia. London: Routledge, pp. 85-114.

Henderson, J. (1999) 'Uneven crises: institutional foundations of East Asian economic turmoil', Economy and Society 28(3): 327-68.

Henderson, J. and Castells, M. (eds) (1987) Global Restructuring and Territorial Development. London: Sage Publications.

Hess, M. (1998) Glokalisierung, industrieller Wandel und Standortstruktur. Munich: VVF.

Heyzer, N. (1986) Working Women in Southeast Asia. Milton Keynes: Open University Press.

Hill, H. (1996) Southeast Asia's Emerging Giant: Indonesian Economic Policy and Development since 1996. Cambridge: Cambridge University Press.

Hughes, A. (2000) 'Retailers, knowledge and changing commodity networks: the case of the cut flower trade', Geoforum 31: 175-90.

Humphrey, J. and Schmitz, H. (2001) 'Governance in global value chains', IDS Bulletin 32(3): 19-29.

Hutton, W. (1995) The State We're In. London: Jonathan Cape.

Hutton, W. (2001) 'Why the Germans are right about us', The Observer, 27 May. 
Jackson, P. (1999) 'Commodity cultures: the traffic in things', Transactions of the Institute of British Geographers 24: 95-108.

Jenkins, R. (1987) Transnational Corporations and Uneven Development. London: Methuen.

Jessop, B. (ed.) (2001) Regulation Theory and the Crisis of Capitalism: Volume IThe Parisian School. Cheltenham: Edward Elgar.

Kaplinsky, R. (1998) 'Globalisation, industrialisation and sustainable growth: the pursuit of the nth rent', Discussion Paper 365, Institute of Development Studies, University of Sussex.

Kaplinsky, R. (2000) 'Spreading the gains from globalisation: what can be learned from value chain analysis?', Working Paper 110, Institute of Development Studies, University of Sussex.

Lane, C. (1989) Industry and Society in Europe. Cheltenham: Edward Elgar.

Law, J. (1999) 'After ANT: complexity, naming and typology', in J. Law, J. and J. Hassard (eds), Actor-network Theory and After. Oxford: Blackwell, pp. 1-14.

Lenz, B. (1997) 'Das Filière-Konzept als Analyseinstrument der organisatorischen und räumlichen Anordnung von Produktions- und Distributionsprozessen', Geographische Zeitschrift 85(1): 20-33.

Markusen, A. (1999) 'Fuzzy concepts, scanty evidence, policy distance: the case for rigor and policy relevance in critical regional studies', Regional Studies 33(9): 869-84.

Murdoch, J. (1998) 'The spaces of actor-network theory', Geoforum 29(4): 357-74.

Mitter, S. and Rowbotham, S. (eds) (1995) Women Encounter Technology. London: Routledge.

Oinas, P. (1997) 'On the socio-spatial embeddedness of business firms', Erdkunde 51(1): 23-32.

Pike, A., Lagendijk, A. and Vale, M. (2000) 'Critical reflections on "embeddedness" in economic geography: the case of labour market governance and training in the automotive industry in the North-East region of England', in A. Giunta, A. Legendijk and A. Pike (eds), Restructuring Industry and Territory. The Experience of Europe's Regions. London: The Stationery Office, pp. 59-82.

Porter, M. (1985) Competitive Advantage: Creating and Sustaining Superior Performance. London: Macmillan.

Porter, M. (1990) The Competitive Advantage of Nations. London: Macmillan.

Raikes, P., Jensen, M.F. and Ponte, S. (2000) 'Global commodity chain analysis and the French filiere approach: comparison and critique', Economy and Society 29(3): 390-417.

Sassen, S. (1999) 'Servicing the global economy: reconfigured states and private agents', in K. Olds, P. Dicken, P.K. Kelly, L. Kong and H. W-C. Yeung (eds), Globalisation and the Asia-Pacific. London: Routledge, pp. 149-62.

Sayer, A. (2000) 'Markets, embeddedness and trust: problems of polysemy and idealism', mimeo, Department of Sociology, University of Lancaster.

Schmitz, H. and Hewitt, T. (1992) 'An assessment of the market reserve for the Brazilian computer industry', in H. Schmitz and J. Cassiolato (eds) Hi-Tech for Industrial Development: Lessons from the Brazilian Experience in Electronics and Automation. London: Routledge, pp. 21-52.

Scott, A.J. (1998) Regions and the World Economy: The Coming Shape of Global Production, Competition and Political Order. Oxford: Oxford University Press.

Sklair, L. (1993) Assembling for Development (2 ${ }^{\text {nd }}$ Edition). San Diego: University of California Center of US-Mexico Relations.

Sklair, L. (1995) Sociology of the Global System (2 ${ }^{\text {nd }}$ Edition). London: Prentice Hall. 
Stark, D. (1992) 'Path dependence and privatization strategies in East-Central Europe', East European Politics and Societies 6(1): 17-51.

Storper, M. and Salais, R. (1997) Worlds of Production. The Action Frameworks of the Economy. Cambridge/Mass.: Harvard University Press.

Sturgeon, T.J. (2001) 'How do we define value chains and production networks?', IDS Bulletin 32(3): 9-18.

Swyngedouw, E. (1997) 'Homing in and spacing out: re-configuring scale', Paper presented at the Deutscher Geographentag Conference, Bonn, 6-11 October.

Turok, I. (1993) 'Inward investment and local linkages: how deeply embedded is "Silicon Glen"?', Regional Studies 27(5): 401-18.

Wade, R. (1990) Governing the Market. Princeton: Princeton University Press.

Weiss, L. (1999) 'State power and the Asian crisis', New Political Economy 4(3): $317-42$.

Whatmore, S. and Thorne, L. (1997) 'Nourishing networks: alternative geographies of food', in D.J. Goodman and M.J. Watts (eds), Globalizing Food: Agrarian Questions and Global Restructuring. London: Routledge, pp. 287-304.

Whitley, R. (1996) 'Business systems and global commodity chains: competing or complementary forms of economic organization?', Competition and Change 1(4): 411-25.

Whitley, R. (1999) Divergent Capitalisms. Oxford: Oxford University Press.

Yeung, H. W-C. (1998) 'The social-spatial constitution of business organisation: a geographical perspective', Organization 5(1): 101-28.

Young, S., Hood, N. and Wilson, A. (1994) 'Targeting policy as a competitive strategy for European inward investment agencies', European Urban and Regional Studies 1(2): 143-59.

Zysman, J. (1983) Governments, Markets and Growth: Financial Systems and the Politics of Industrial Change. Oxford: Robertson. 